press, Internet and social networks. Analytical report. The Levada Center]. https:// www.levada.ru/cp/wp-content/uploads/2019/08/LevadaMedia2019-1.pdf

14. https://fom.ru/SMI-i-internet/14256

15. D. H. McKnight, N.L. Chervany. The Meanings of Trust (1996). http://www. misrc.umn.edu/workingpapers/fullPapers/1996/9604_040100.pdf

16. Obraz zhurnalista v massovom soznanii rossiyan — rezul'taty issledovaniya. Fond “Mediastandart”, Issledovatel'skaya gruppa “Tsirkon”, Komitet grazhdanskikh initsiativ. [The image of a journalist in the mass consciousness of Russians - research results. Mediastandart Foundation, research group "ZIRCON", Committee of civil initiatives.] Moscow (2018). http://www.msindex.ru/wp-content/uploads/2018/10/ Obraz-zhurnalista-v-massovomsozdanii-rossiyan_doklad.pdf

DOI 10.15826/B978-5-7996-3081-2.41

\title{
Reflection of University Students' Interethnic Tolerance in Russian Media Education: Past and Present
}

\section{Chelysheva Irina}

Rostov State University of Economics, Rostov-on-Don, Russia

ivchelysheva@yandex.ru

Abstract. The article is devoted to the analysis of the issue of students' interethnic tolerance in Russian scientific research. The aim is to identify the main periods of the development of interethnic tolerance issue in the post-Soviet times. Analyzing social and cultural, theoretical and methodological aspects of the research in the context of media education is strategically important for defining the main approaches to the further development of media education.

Keywords: Interethnic tolerance, media education, periods of development, post-Soviet times

\section{Introduction}

The aggravation of interethnic relations among younger generation in the contemporary social and cultural conditions make it relevant to analyze 
this issue for searching for solutions. One of the important factors that have a significant impact on all spheres of life of youth today is media education (a part of pedagogy that teaches students in schools and at universities to understand the logic of mass communication). The analysis of the main statements that make up the social and cultural and theoretical-methodological basis of the research of interethnic tolerance issue allows us to define a number of concepts that are related to the issue. Here is the list of them: the culture of interethnic communication, multicultural education, ethnic identity, national identity, interethnic peace and harmony, basic national values, etc.

\section{History of problem}

Background research of the theoretical and methodological fundamentals in the study of the interethnic tolerance issue in Russia can be found in the works of M.M. Bakhtin, N. A. Berdyaev, V.S. Bibler, V.S. Soloviev, P. A. Sorokin, L. N. Tolstoy, N. K. Roerich, etc.

After the events in October 1917 the religious and philosophical views of Russian scholars about tolerance and non-resistance to evil were replaced by new priorities, among which the class struggle was at the forefront. In the years $20 \mathrm{~s}-30$ s of the twentieth century after having experienced a revolution, a civil war, devastation, mass resettlement, interethnic problems were solved quite cardinally in Russia. The basic principles of neighborhood and national unity in the Soviet education system were implemented into international education, which, along with labor, patriotic, moral, physical, and other types of educations, was an important factor in the formation of a comprehensively developed personality of future communism builders. Interethnic conflicts (Nagorno-Karabakh, Sumgait, Bak, etc.) aggravated, in the second half of the1980s, the state policy restructuring, and later the collapse of the USSR, and led to the dismissal of the concept of international education in the previous ideological key.

A number of research studies of the post-Soviet period covered the interethnic tolerance issue and the analysis of works of the 1990s [Bachmair, 1997] has shown that at that time the research was concentrated on a general range of issues concerning theoretical and methodological fundamentals of the study of interethnic relations, the ethnic pedagogical culture of a democratic society, the development of multicultural education and the upbring- 
ing of a younger generation in Russia according to new conditions such as the restructuring of the entire social system.

During that period of time a number of important documents of the world community was adopted with the aim to solve the problems of interethnic tolerance. UNESCO documents played an important role in the development of the issue of tolerance in scientific circles. Thus, on the $16^{\text {th }}$ of November 1995 at the General Conference of UNESCO Declaration of Principles on Tolerance was adopted, proclaiming tolerance as the most important principle and "a necessity for peace and for the economic and social advancement of all peoples [UNESCO Declaration, 1995]". It emphasized the importance of tolerance in the era of globalization: "It is an age marked by the globalization of the economy and by rapidly increasing mobility, communication, integration and interdependence, large-scale migrations and displacement of populations, urbanization and changing social patterns. Since every part of the world is characterized by diversity, escalating intolerance and strife potentially menaces every region. It is not confined to any country, but is a global threat [UNESCO Declaration, 1995]".

The analysis of a range of problems covered by research of the first decade of the 21st century, we can state a wider range of issues related to the of interethnic tolerance problem. Russian scholars studied problems of multicultural education and interethnic communication, the culture of interethnic communication in multinational schools, organization of ethnic regional educational systems, social and psychological basics of interethnic interaction, etc. The first research on system analysis of interethnic tolerance issue was presented. The analysis of foreign works of the last years of the twentieth century has shown that in many English-speaking countries with a high proportion of migrants, attention is paid to the interethnic tolerance building from an early age. Issues of preventing interethnic intolerance and fostering a tolerant attitude towards representatives of other ethnic cultures were also important in English-language research.

Since the year 2000, issues of interethnic tolerance, national harmony, harmonization of interfaith and interethnic relations, the culture of interethnic communication started to develop in a new direction and began to be associated with the rapid development of the media sphere both in Russian society and in English-speaking countries. A number of Russian works in the field of psychology, pedagogy, sociology and philology were devoted to tolerance building issue in the context of the developing media culture 
and possible media education for students: V. A. Vinichenko, E. Yu. Zhmyrova, L. A. Ivanova, E. D. Pavlova, O. V. Pechinkina, A. V. Fedorova, N. F. Khilko, N. Yu. Khlyzova, I. V. Chelysheva, M. N. Cherkasova, T. I. Chechet, etc. During these years works of English-speaking researchers also partially covered the interethnic tolerance issue among the younger generation in the media educational context: L. Masterman, B. Bachmeier, D. Buckingham, J. Bryant and S. Thompson, D. Rushkoff, N. Andersen, J. Panjente and O. Malley et al.

\section{Results}

Russian and foreign (English-speaking) studies indicate that using the experience of foreign media pedagogy for the development of interethnic tolerance among the student youth can contribute to the development of an independent, conscious position of respect, trust and a peaceful attitude towards other peoples, based on constructive dialogues, non-violent interaction and opportunities for intercultural exchange.

Having studied various approaches to the interethnic tolerance issue, which in Russian and foreign (English-speaking) scientific research has many definitions and characteristics, we can make a list of the main substantive components of interethnic tolerance, among them there are mutual understanding, constructive dialogue, mutual respect and cooperation of representatives of different nationalities and ethnic groups, mutual acceptance of traditions and cultural values in the context of cultural diversity. The analysis shows that interethnic tolerance can be defined as a positive active type of relations between representatives of different ethnic groups and in a multicultural society this means equal positions and a positive attitude towards other nations based on deep respect for representatives of their own nationality.

Based on the research on interethnic tolerance as a complex phenomenon, the main structural components of the latter are cognitive, value emotional and activity-related ones. The cognitive component includes "knowledge about the ethnic identity of people at the level of ideas, concepts (freedom, equality, responsibility for maintaining this ethnic diversity demonstrated in respect for one's own and other ethnic groups), at the level of judgments (sympathy, empathy, interaction), at the level of ideas tolerance performs an informative and systematizing function" [Paina, 2004, 8]. The value-emotional component defines the attitude towards representatives 
of other ethnic groups, cultures; the activity related component determines a self-realization of the personality and its level of willingness to be involved and active in the process of interaction with representatives of other nations.

\section{Conclusion}

Research of the genesis and development of the interethnic tolerance issue made it possible to distinguish two main periods in the reflection of this problem in the Russian and English-language media education of the post-Soviet time (1992-2020).

The first period (1992-2000): in Russia this period is associated with the development of a theoretical and methodological database in the study of the issues concerning interethnic relations, the ethnic pedagogical culture of a democratic society, the development of multicultural education and the upbringing of a younger generation in Russia according to new conditions. During that period, the topic of media education's role in the development of interethnic tolerance among the younger generation was absent in Russian studies. For Western (English-speaking countries), this period is characterized by active development of multicultural approaches to education, creation of programs for students of various national groups. These problems in the media educational context were partially covered in works of L. Masterman [Masterman, 1997], B. Bachmeier [Andersen, 1999], N. Andersen [Andersen, 1999], J. Panjente and O. Malley [Pungente, 1999] and others. English-language studies of that period mainly emphasized the development of critical thinking, implementation of media education in secondary schools, elaboration of methodological tools for media education process, historical development of media culture and media education, etc.

The second period (2001-2020) is characterized by a wider range of issues related to the interethnic tolerance problem and covered in Russian and English-language scientific research. So, in the forefront there were issues of multicultural education, interethnic communication; the culture of interethnic communication in a multinational school; organization of ethnic regional educational systems; elaboration of social and psychological fundamentals of interethnic interaction. The first Russian and foreign studies on a system analysis of the interethnic tolerance issues appeared. Development of a new sector of Russian and foreign research that was studying the possibilities of media culture and media education for the development of interethnic tolerance among younger generation: methodological principles of the me- 
dia education process; analysis of the mechanisms of media influence on the audience; the impact of screen media texts on children and the youth and the development of media culture among a younger generation; practical aspects of the development of media education and the development of media literacy, etc. During that period Russian researchers also began to take an active part in development of the interethnic tolerance issue together with the study of media and media education including the following issues: the use of media education's potential in the development of personal tolerance; the possibilities of cinematography as a means of fostering tolerance; development of the national information culture among a younger generation by means of media education; media linguistic and media critical aspects in representing media events and media images using a language of hate; an integrated approach to personal problems of the development of critical thinking and tolerance in teaching foreign languages using materials of mass media; multicultural aspects of the media education process in the context of learning foreign languages, etc.

The analysis of the historical development of the interethnic tolerance issue in Russia and in English-speaking countries in 1992-2020 justified the fact that interethnic tolerance issues among a younger generation are strategically important for the world community. Documents of the international community, adopted normative legal acts, and scientific research of recent decades are the evidence.

\section{Acknowledgements}

The research was carried out with the financial support of the Russian Foundation for Basic Research (RFBR) as a part of the scientific project No. 19-013-00030 "Reflection of the issue of interethnic tolerance of the student youth in Russian and English-language media education in the post-Soviet period (1992-2020)" carried out at the Rostov State University of Economics. The project manager is $\mathrm{PhD}$ in Pedagogy, Associate Professor I. V. Chelysheva.

\section{References:}

1. B. Bachmair. Cosa fa la TV ai bambini? Edutrice Elle di ci. Leumann, Torino (1997), pp. 163.

2. Dekalaratsiya printsipov toleranntnosti, utverzhdennaya rezolyutsiyey general'noy konferentsii YUNESKO ot 16 noyabrya 1995 goda [UNESCO Declaration 
of Principles on Tolerance adopted on Novermber $\left.16^{\text {th }} 1995\right]$. http://www.tolerance. ru/toler-deklaraciya.php (Accessed 23 June 2019).

3. L. I. Paina. Vospitaniye etnicheskoy tolerantnosti u starsheklassnikov v regional'noy sotsiokul'turnoy srede: avtoref. ... kand. ped. nauk [Education of ethnic tolerance among senior pupils in the regional socio-cultural environment: $\mathrm{PhD}$ thesis]. Orenburg (2004).

4. L. Masterman. A Rational for Media Education. In: Media Literacy in the Information Age. Transaction Publishers, New Brunswick and London (1997), pp. 15-68.

5. N. Andersen, B. Duncan, J. J. Pungente. Media Education in Canada the Second Spring / Von Feilitzen and Carlsson (Eds.). Children and Media: Image. Education. Participation. Geteborg: The UNESCO International Clearinghouse on Children and Violence on the Screen at Nordicom. (1999), pp. 139-162.

6. J. J. Pungente, M. O’Malley. More Than Meets the Eye: Watching Television Watching Us. McClelland \& Stewart Inc., Toronto (1999). 